\title{
Changes of community structure and functional feeding groups of benthic macrofauna after mangrove afforestation in a subtropical intertidal zone, China
}

\section{Yiyong Rao ( $547484064 @ q q . c o m$ )}

South China Sea Fisheries Research Institute https://orcid.org/0000-0002-3974-6980

Lizhe Cai

Xiamen University

Xiping Zhou

Xiamen University Tan Kah Kee College

\section{Sujing Fu}

Xiamen University

\section{Wenqing Peng}

Xiamen University

\section{Xinwei Chen}

Xiamen University

\section{Bin Zheng}

Xiamen University

\section{Research Article}

Keywords: benthic macrofauna, functional feeding groups, community structure, mangrove afforestation, subtropical intertidal zone

Posted Date: July 6th, 2021

DOl: https://doi.org/10.21203/rs.3.rs-287527/v1

License: (9) This work is licensed under a Creative Commons Attribution 4.0 International License. Read Full License

Version of Record: A version of this preprint was published at Wetlands on November 16th, 2021. See the published version at https://doi.org/10.1007/s13157-021-01489-4. 


\section{Abstract}

Afforestation is a primary response to the loss and degradation of mangroves worldwide. The successful restoration of mangrove ecosystems is in part indicated by the rebuilding of macrobenthic community. However, the community dynamic of benthic macrofauna after mangrove afforestation was poorly known. Here, three quarterly surveys $(2006-2007,2014-2015,2019-2020)$ of the benthic macrofauna and sediment grain size were conducted in a mix-planted mangrove stand (Kandelia obovata + Sonneratia apetala) in Xiamen Tong'an Bay, China. Our results showed that the community structure of benthic macrofauna differed significantly after mangrove afforestation. These differences were accompanied by the declines in the species number, abundance, biomass, and diversity $(H)$, as well as the fining of sediments. We also found that the epifauna and infauna exhibited different adaptabilities to mangrove vegetation. Additionally, shifts in the composition of the functional feeding groups were observed, indicating the modification of trophic structure after mangrove afforestation. We recommend that future mangrove afforestation programs call for a guide to coordinate habitats for different taxa.

\section{Introduction}

Mangroves are essential ecosystem in tropical and subtropical coastal intertidal regions, offering an array of services such as protection of shorelines, sediment trapping, nutrient processing, and socioeconomic goods (Alongi, 2008; Ewel et al., 1998; Nagelkerken et al., 2008; Walters et al., 2008). Mangroves, however, are negatively impacted by urbanization, pollution, and over-exploitation (Alongi, 2002; Duke et al., 2007; Field, 1999). Consequently, approximately one-third of mangroves have been degraded over the last decades (Alongi, 2002; Bosire et al., 2008). In response, mangrove afforestation programs have been launched worldwide as a way to restore degraded mangrove forests and expand mangrove areas (Leung and Cheung, 2017; Lewis, 2005). One such project is the "South Mangroves and North Tamarisk" is a wetland restoration project in the 13th five-year plan (2016-2020) which is the central government blueprint for China's long-term social and economic policies (Tang et al., 2018).

Previously, the primary objective of mangrove restoration was afforestation (Ellison, 2000). Lewis (1984) discussed for the first time that restoration of mangroves should emphasize ecological values, animal habitats, and detrital food sources for coastal food webs. It is widely known that the three-dimensional structure created by mangroves provide shelter from predators, food, and protection from desiccation for a variety of animal species (Kon et al., 2010; Nagelkerken et al., 2008). Mangrove associated fauna thus can be a useful indicator for judging the success of mangrove restoration (Bosire et al., 2008).

Benthic macrofauna are of great importance in maintaining the structure and function of mangrove ecosystem (Cannicci et al., 2008; Lee, 2008). Benthic macrofauna serve as necessary links between the primary detritus at the base of coastal food webs and the consumers at higher trophic levels (Kristensen et al., 2008; Lee, 2008), and improve aeration and reduce harmful components in the surrounding sediment through their burrowing and feeding activities (Nagelkerken et al., 2008). Therefore, changes in 
the macrobenthic community structure would influence local biodiversity and ecosystem functions (Kristensen et al., 2008; Nagelkerken et al., 2008).

Although mangrove afforestation can successfully re-establish the plant community, the effectiveness of restoring the macrobenthic community remains controversial. The establishment of macrobenthic communities is a complex and time-consuming process, and depends on the physical structure of mangrove and local environmental conditions (Kon et al., 2010; Leung and Cheung, 2017; Pagliosa et al., 2016). Research has shown that mangrove planting can change sediment properties and habitat complexity, which in turn influence the macrobenthic community (Evin and Talley, 2002). Several studies have demonstrated that the macrobenthic community changes with stand age of mangroves in terms of species richness and composition (Chen et al., 2007; Li et al., 2017; Morrisey et al., 2003), functional feeding groups (FFGs) (Chen et al., 2018b; Feng et al., 2014; Feng et al., 2018), and ecological exergy (Chen et al., 2018a). However, previous studies use space-for-time substitution as an alternative approach to evaluating the long-term effects of mangrove plantation or mangrove succession on macrobenthic community. Continuous observation of an identical mangrove stand would help to reduce errors of spatial autocorrelation generated by space-for-time substitution and to better understand the dynamics of macrobenthic community in the mangrove afforestation process, and to our knowledge, such empirical studies are still lacking.

In this study, we explore how sediment properties and macrobenthic community structure change after the mangrove afforestation during three survey periods (2006-2007, 2014-2015, 2019-2020). Generally, benthic macrofauna can be categorized into epifauna (the animals living on the surface of the sediments) and infuana (the animals living in the sediments). Given the distinct characteristics among benthic macrofauna. we therefore assume that the epifauna and infauna have different responses to mangrove vegetation and fauna belonging to different functional feeding groups also respond differently.

\section{Materials And Methods}

\subsection{Study area}

Tong'an Bay is a subtropical semi-enclosed bay located to the northeast of Xiamen Island, China. The mean annual temperature is $20.9{ }^{\circ} \mathrm{C}$, and the mean annual precipitation is $1200 \mathrm{~mm}$. The tidal type is semidiurnal, with a mean tidal range of $4.0 \mathrm{~m}$. In order to establish a mangrove-themed ecotourism area (i.e. Xiatanwei Wetland Park), an initiative proposed by Xiamen municipal government, a ca. 4.5 ha mangrove stand was planted in the intertidal zone of the head of the bay in 2005 (Fig. 1). This stand is mixed with two mangrove species, one is the native species Kandelia obovata, and the other is the exotic species Sonneratia apetala.

\subsection{Field sampling and sample processing}

The sampling of benthic macrofauna and sediment grain size was conducted over three survey periods (2006-2007; 2014-2015; 2019-2020), represented different mangrove ages (1-year, 9-year and 14-year). In 
each sampling period, benthic macrofauna were collected from ten random $25 \mathrm{~cm} \times 25 \mathrm{~cm}$ quadrats at a depth of $30 \mathrm{~cm}$ during the low tide in the spring tide of each season (i.e., January, April, July and October). First, all benthic macrofauna from the sediment surface of each quadrat were collected, and then the sediments within the designated volume were excavated with a shovel. The excavated sediments were washed through a $0.5 \mathrm{~mm}$ mesh sieve, and the residues were transferred to sample containers with $5 \%$ formalin buffer in situ for further identification (Chen et al., 2017). Three extra sediment samples from surface to $10 \mathrm{~cm}$ depth were randomly collected in spring of each survey period for grain size analysis. In the laboratory, benthic macrofauna were identified to the lowest possible taxon, enumerated under a dissecting microscope, and weighted using an electronic balance after blotting surface water off with clean absorbing paper. Then, benthic macrofauna were categorized as epifauna and infauna based on their position relative to the sediment. The sediment grain size was measured using a Mastersizer 2000 particle size analyzer and then was classified into four fractions: gravel (grain diameter $>2 \mathrm{~mm})$, sand $(63 \mu \mathrm{m}-2 \mathrm{~mm})$, silt $(4-63 \mu \mathrm{m})$, and clay $(<4 \mu \mathrm{m})$.

\subsection{Classification of functional feeding groups}

The species identified were assigned to six functional feeding groups based on their feeding modes (Jumars et al., 2015; Macdonald et al., 2010): (1) phytophages (PH), which feed primarily on living plant tissue and medium to large algae; (2) planktophages (PL), which filter plankton and suspended particles from water column; (3) carnivores (CA), which prey on other animal; (4) surface deposit feeders (SD), which feed on detritus from the sediment surface; (5) subsurface deposit feeders (SSD), which feed on detritus located beneath the sediment-water interface; and (6) omnivores (OM), which can use different types of food sources.

\subsection{Statistical Analyses}

The species number, abundance, biomass, and Shannon index $\left(H^{\prime}, \log _{2}\right.$ based) of epifauna, infauna, and benthic macrofauna (epifauna and infauna) were calculated for each quadrat. The proportions of the species number, abundance, and biomass of FFGs in each quadrat were summarized. One-way ANOVA was used to test whether the mean values of the community parameters (i.e., species number, abundance, biomass, and $H$ ) and the proportions of FFGs (in terms of species number, abundance, and biomass) exhibited significant differences among the stand age groups (i.e., 1-year, 9-year, and 14-year) and season groups (i.e., spring, summer, autumn, and winter). Prior to the ANOVA test, Levene's test was performed to assess the homogeneity of variance. If the homogeneity of variance is violated, an adjusted $p$ value from Welch's ANOVA is adopted. Only when the equality of mean values is rejected $(P<0.05)$, a pairwise comparison of mean values is implemented by Tukey's HSD test (Tamhane's T2 test for unhomogeneous variables). The above univariate analyses were performed in SPSS 22.0.

The abundance data of benthic macrofauna from each quadrat were pooled to form the benthic macrofaunal composition in each sampling time (stand age plus season) for multivariate analyses. The similarity of benthic macrofaunal communities among each sampling time was determined using the 
Bray-Curtis coefficient based on the square-root transformed abundance data. The CLUSTER and nMDS analyses based on the Bray-Curtis similarity were used to explore the temporal variations in benthic macrofaunal community structure, and the significant temporal groups were detected using the SIMPROF procedure (1000 permutations, $5 \%$ significance level). The SIMPER analysis was then implemented to examine the contribution of each species to the dissimilarity between the temporal groups ( $70 \%$ cut-off). The above multivariate analyses were run in PRIMER 7.0.

\section{Results}

\subsection{Sediment grain size}

The content of sand in the sediment declined from 35.9\% (1-year) to $0.2 \%$ (14-year); in contrast, the content of silt and clay increased over time, from $48.1 \%$ and $16.0 \%$ to $70.2 \%$ and $29.6 \%$. No gravel was detected in all sediment samples (Fig. 2).

\subsection{Epifauna and infauna}

A total of 77 benthic macrofauna species, including 39 epifauna species (50.6\%) and 38 infauna species $(49.4 \%)$, were recorded during the three sampling periods in the mangrove stand in Xiamen Tong'an Bay (Table S1). The species number of benthic macrofauna decreased over time, 53 species (23 epifauna species and 30 infauna species) in the 1-year mangrove stand, 47 species (24 epifauna species and 23 infauna species) in the 9-year mangrove stand, and 25 species (16 epifauna species and 9 infauna species) in the 14-year mangrove stand.

Results of one-way ANOVA showed that the mean values of species number, abundance, biomass, and Shannon index $(H)$ represented by epifauna, infauna, and benthic macrofauna were significantly different among the stand age groups (Table S2). Figure 3 summarized the temporal variations in the species number, abundance, biomass, and $H^{\prime}$ represented by epifauna, infauna, and benthic macrofauna (i.e., total). The mean values of species number, abundance, biomass, and $H^{\prime}$ of epifauna in the first sampling period (1-year) were significantly higher than those in the last two sampling periods (9-year and 14-year), and the mean values of species number and abundance of epifauna in the second sampling period (9-year) were significantly higher than those in the last sampling period (14-year). The mean values of species number, abundance, and $H^{\prime}$ of infauna in the first two sampling periods (1-year and 9year) were significantly higher than those in the last sampling period (14-year), while the mean value of the biomass of infauna was highest in the second sampling period (9-year). In total, the mean values of species number and abundance of benthic macrofauna decreased significantly over time; the mean value of biomass of benthic macrofauna in the first sampling period (1-year) was significantly higher than that in the last two sampling periods (9-year and 14-year); and the mean values of $H^{\prime}$ of benthic macrofauna in the first two sampling periods (1-year and 9-year) were significantly higher than that in the last sampling period (14-year). 
For epifauna, there were no significant differences in the mean values of species number, abundance, biomass, and $H^{\prime}$ among the season groups; for infauna, the mean values of species number, abundance, and biomass exhibited significant differences among the season groups, in general, showing peaks in spring; while no significant differences were identified for the mean values of $H^{\prime}$ regardless of the living position of the fauna (Table S2).

\subsection{Functional feeding groups}

Among the 77 species, 15 species were assigned to $\mathrm{PH}, 15$ species $\mathrm{PL}, 15$ species CA, 11 species SD, 12 species SSD, and 9 species OM based on their feeding modes (Table S1). The results of one-way ANOVA showed that most FFGs varied significantly among the stand age groups in terms of the proportion of species number, abundance, and biomass, except the species number of SD and OM and the abundance and biomass of CA (Table S3). Figure 4 summarized the temporal variations in the proportions of species number, abundance, and biomass represented by FFGs. The proportions of the species number, abundance, and biomass represented by $\mathrm{PH}$ in the second sampling period (9-year) were significantly lower than those in the other two sampling periods (1-year and 14-year, $\mathrm{P}<0.001$, when multiple $\mathrm{P}$-values are involved, select the maximum, hereinafter) and reached maximum in the last sampling period (14year). The proportions of species number represented by $P L$ deceased significantly over time $(P<0.05)$, and the proportions of abundance and biomass represented by PL in the last sampling period (14-year) were significantly lower than those in the first two sampling periods (1-year and 9-year, $\mathrm{P}<0.001)$. The proportion of species number represented by CA in the last sampling period (14-year) was significantly lower than that in the first two sampling periods (1-year and 9-year, $P \leq 0.007)$. The proportion of abundance represented by SD in the second sampling period (9-year) was lower than that in the other two sampling periods (1-year and 14-year) but exhibited significant differences only between 1-year and 9year $(P=0.015)$; the proportion of biomass represented by SD decreased over time but exhibited significant differences only between 1 -year and 14-year $(P=0.001)$. The proportions of species number, abundance, and biomass represented by SSD in the second sampling period (9-year) were significantly higher than those in the other two sampling periods (1-year and 14-year, $\mathrm{P} \leq 0.003$ ) and reached minimum in the last sampling period (14-year) except the proportion of the biomass, which the minimum occurred in the first sampling period (1-year). The proportions of the species number, abundance, and biomass represented by $\mathrm{OM}$ increased over time but exhibited significant differences only between the first (1-year) and last (14-year) sampling periods in terms of the proportions of the abundance $(P=0.023)$ and biomass $(P=0.018)$.

Significant seasonal changes were observed in the proportions of species number represented by OM, abundance represented by $\mathrm{PL}, \mathrm{SD}$, and $\mathrm{OM}$, and biomass represented by $\mathrm{PL}$ (Table S3). The proportions of abundance and biomass represented by $\mathrm{PL}$ in spring were significantly higher than those in the remaining seasons $(P \leq 0.040)$. The proportion of abundance represented by SD in spring was lower than that in the remaining seasons but exhibited significant differences only between spring and summer $(P=$ $0.028)$ and between spring and winter $(P=0.038)$. The proportion of species number represented by $O M$ 
in spring was significantly higher than that in autumn $(P=0.026)$, whereas no significant differences were detected for the proportion of abundance by pairwise comparisons.

\subsection{Community structure}

At the $30 \%$ similarity level, three groups with significant differences (SIMPROF test, $P<0.05$ ), which were consistent with the stand age groups, can be obtained through CLUSTER analysis (Fig. S1). More importantly, the nMDS ordination plot, overlaying the minimum spanning tree, indicated the gradual changes of macrobenthic community over time (Fig. 5).

The SIMPER analysis identified 30 species as most contributing to the intergroup dissimilarities (Table 1). Among the 30 species, the mean abundance of most epifauna (9/14) declined dramatically during the first two sampling periods (1-year and 9-year) and then remained stable or declined imperceptibly during the last two sampling periods (9-year and 14-year), while the mean abundance of two epi-crustaceans, i.e., Sesarma dehaani and S. plicata, with PH feeding mode increased slightly during the last two sampling periods (9-year and 14-year); the mean abundance of most infauna (9/16) increased during the first two sampling periods (1-year and 9-year) and then declined during the last two sampling periods (9year and 14-year), however, the mean abundance of several infauna, e.g., oligochaetes Limnodriloides sp. and polychaetes Paraprionospio cristata, declined over time. The top five contributive species to the dissimilarities of macrofaunal communities between the first (1-year) and second (9-year) sampling periods and between the first (1-year) and last (14-year) sampling periods could be both epifauna and infauna, whereas the top five contributive species to the dissimilarity between the second (9-year) and last (14-year) sampling periods were infauna only. In addition, the feeding modes of the top five contributive species were among PL, SD, and SSD.

Table 1. The abundance and contribution rates of species to the dissimilarity of macrofaunal communities between the temporal groups (cut-off applied at 70\%). The contribution rates of the top five contributing species are in bold. PH, PL, CA, SD, SSD, and OM represent phytophages, planktophages, carnivores, surface deposit feeders, subsurface deposit feeder and omnivores, respectively. 


\begin{tabular}{|c|c|c|c|c|c|c|c|}
\hline \multirow[t]{2}{*}{ Species } & \multirow{2}{*}{$\begin{array}{l}\text { Functional feeding groups } \\
\text { (FFGs) }\end{array}$} & \multicolumn{3}{|c|}{ Abundance (ind. $/ \mathrm{m}^{2}$ ) } & \multicolumn{3}{|c|}{ Contribution rate (\%) } \\
\hline & & $\begin{array}{l}1- \\
\text { year }\end{array}$ & $\begin{array}{l}9- \\
\text { year }\end{array}$ & $\begin{array}{l}14- \\
\text { year }\end{array}$ & $\begin{array}{c}1- \\
\text { year } \\
\text { vs. } \\
9- \\
\text { year }\end{array}$ & $\begin{array}{c}\text { 1-year } \\
\text { vs. } \\
14- \\
\text { year }\end{array}$ & $\begin{array}{c}9- \\
\text { year } \\
\text { vs. } \\
14- \\
\text { year }\end{array}$ \\
\hline \multicolumn{8}{|l|}{$\begin{array}{l}\text { Epifauna } \\
\text { Gastropods }\end{array}$} \\
\hline Assiminea brevicula & SD & 128.5 & 0.8 & 0.0 & 6.3 & 7.9 & \\
\hline Cerithidea cingulata & $\mathrm{PH}$ & 10.5 & 0.0 & 0.0 & 2.2 & 2.6 & \\
\hline Littoraia melanostoma & $\mathrm{PH}$ & 6.0 & 0.0 & 0.0 & 1.6 & 2.0 & \\
\hline \multicolumn{8}{|l|}{ Crustaceans } \\
\hline Alpheus sp. & $\mathrm{CA}$ & 1.0 & 4.8 & 1.2 & & & 2.6 \\
\hline $\begin{array}{l}\text { Chasmagnathus } \\
\text { convexus }\end{array}$ & SD & 0.0 & 5.2 & 2.8 & & & 2.6 \\
\hline Corophium sp. & PL & 663.5 & 0.8 & 0.0 & 7.0 & 7.9 & \\
\hline Exopalaemon orientalis & $\mathrm{CA}$ & 46.5 & 4.8 & 0.4 & 3.2 & 4.4 & \\
\hline Ilyoplax tansuiensis & SD & 49.0 & 10.8 & 4.0 & 3.2 & 3.2 & 3.2 \\
\hline $\begin{array}{l}\text { Macrophthalmus } \\
\text { definitus }\end{array}$ & SD & 62.0 & 4.8 & 4.4 & 4.4 & 4.8 & 2.2 \\
\hline Metapenaeus ensis & $\mathrm{CA}$ & 11.5 & 2.4 & 0.8 & 1.5 & 1.8 & \\
\hline Metaplax longipes & SD & 0.5 & 5.6 & 0.0 & & & 2.4 \\
\hline Sesarma dehaani & $\mathrm{PH}$ & 0.0 & 0.4 & 10.4 & & 2.5 & 4.1 \\
\hline Sesarma plicata & $\mathrm{PH}$ & 0.0 & 0.0 & 4.0 & & & 2.2 \\
\hline Uca arcuata & SD & 16.0 & 1.6 & 0.8 & 2.0 & 2.5 & \\
\hline \multicolumn{8}{|l|}{ Infauna } \\
\hline \multicolumn{8}{|l|}{ Nemertean } \\
\hline Cerebratulina sp. & $\mathrm{CA}$ & 6.5 & 12.4 & 0.0 & & 1.9 & 3.9 \\
\hline \multicolumn{8}{|l|}{ Oligochaetes } \\
\hline Limnodriloides sp. & SSD & 41.5 & 2.0 & 0.0 & 2.9 & 4.0 & \\
\hline \multicolumn{8}{|l|}{ Polychaetes } \\
\hline Capitella capitata & SSD & 0.5 & 8.4 & 1.6 & 1.6 & & 2.8 \\
\hline Ceratonereis tripartita & $\mathrm{OM}$ & 10.0 & 0.0 & 0.0 & 1.7 & 2.0 & \\
\hline Chaetozone setosa & SSD & 1.5 & 208.4 & 1.2 & 6.3 & & 11.9 \\
\hline Eteone delta & $\mathrm{CA}$ & 13.0 & 0.0 & 0.0 & 2.5 & 3.0 & \\
\hline Glycera chirori & $\mathrm{CA}$ & 3.0 & 3.2 & 0.0 & & & 2.1 \\
\hline Mediomastus chinensis & SSD & 134.0 & 0.0 & 1.2 & 6.5 & 7.2 & \\
\hline Neanthes glandicinta & $\mathrm{OM}$ & 0 & 19.6 & 6.0 & 1.8 & 1.9 & 3.1 \\
\hline Nephtys oligobranchia & SSD & 6.0 & 24.8 & 0.8 & 1.8 & & 5.2 \\
\hline Notomastus latericeus & SSD & 3.0 & 12.4 & 0.0 & & & 4.3 \\
\hline Paraprionospio cristata & PL & 103.5 & 89.6 & 0.8 & 6.4 & 7.3 & 4.4 \\
\hline Prionpspio japonica & PL & 1.0 & 17.6 & 0.0 & 2.4 & & 5.7 \\
\hline Scoloplos rubra & SSD & 2.0 & 10.4 & 0.4 & & & 3.2 \\
\hline Spio martinensis & PL & 7.0 & 0.8 & 0.0 & 1.5 & 2.2 & \\
\hline \multicolumn{8}{|l|}{ Sipuncula } \\
\hline $\begin{array}{l}\text { Phascolosoma } \\
\text { arcuatum }\end{array}$ & SSD & 0.0 & 21.2 & 1.2 & 3.0 & & 5.5 \\
\hline Dissimilarity (\%) & & & & & 79.5 & 90.0 & 80.8 \\
\hline
\end{tabular}

\section{Discussion}


There is increased evidence that macrobenthic communities change with the stand age of mangrove or the stages of mangrove succession. For instance, Morrisey et al. (2003) found that the faunal taxa number in the younger stands (3-12 years) were generally higher than that in the older stands (> 60 years). Chen et al. (2007) also demonstrated that the younger stands (4-year and 7-year) had more benthic macrofauna species than older ones (19-year and 43-year), and the dominant species between the younger and older stands were different. Chen et al. (2018b) noted that as mangrove succession progressed, the proportion of omnivores in benthic macrofaunal communities significantly increased, whereas the proportion of detritivores significantly decreased. Consistent with these findings, our results suggested that the community structure of benthic macrofauna differed significantly with the stand age of the mangrove in Xiamen Tong'an Bay. Such differences were accompanied by the declines in species number, abundance, biomass, and diversity $(H)$ and associated with the changes in sediment grain size over time. Furthermore, we also found that epifauna and infauna exhibited different adaptabilities to mangrove vegetation, and the trophic structure was changed.

Compared with the 1-year mangrove stand, the species number, abundance, biomass, and diversity $(H)$ of epifauna in the 9-year mangrove stand declined significantly, while those of infauna remained steady except for biomass (Fig. 3). Albeit mangrove leaf litter provide a certain amount of organic matter, high concentration of tannins in leaves hinder the direct utility for consumers (Li et al., 2017). Benthic macrofauna usually prefer the relatively nutrient-rich food sources, such as benthic microalgae, rather than fresh mangrove leaves (Feng et al., 2018; Giarrizzo et al., 2011; Nagelkerken et al., 2008). The physical structure of mangrove, such as the canopy cover and root density, would change with the growth of mangrove (Bosire et al., 2008). Satellite images clearly indicate that the canopy cover of mangrove stand increases over time in Xiamen Tong'an Bay (Fig. 1). Mangrove vegetation reduces the availability of light, thus affecting the growth of microalgae (Kon et al., 2010; Whitcraft and Levin, 2007). Hence, the decline of the proportions of PH and SD may be attributed to the modification of microalgae by mangrove (Fig. 4). For example, the abundances of phytophagous Cerithidea cingulate and surface deposit feeder Macrophthalmus definitus decreased dramatically in the second sampling period (Table 1). Meanwhile, the fauna with these two feeding modes are usually epifauna (Table S1), and this accounts for the significant drops of epifauna.

Although the community parameters of infauna did not change during the first two sampling periods, the species composition was different. For instance, the tube dwelling polychaete Chaetozone setosa increased from $1.5 \mathrm{ind} . / \mathrm{m}^{2}$ to $208.4 \mathrm{ind} . / \mathrm{m}^{2}$, while the free-living polychaete Mediomastus chinensis declined from 134.0 ind. $/ \mathrm{m}^{2}$ to 0.0 ind. $/ \mathrm{m}^{2}$ (Table 1). Leung (2015) found that root biomass was the most important factor in determining the infaunal community. The increased complexity of roots establishes blocks in the sediment, making it difficult for the free-living infauna to create burrows (Leung, 2015; Li et al., 2017). Additionally, by reducing water flow, the root system traps fine and organic-rich particles transported by tides or produced from mangrove litter per se (Bird, 1971). In the present study, the finer sediments were observed in the late periods (Fig. 2). However, reduced water flow would depress 
the feeding rate and abundance of suspension feeders (Lana and Guiss, 1991; Peterson et al., 1984). Therefore, the proportions of PL decreased significantly in the mangrove afforestation process (Fig. 4).

As mangrove restoration enhances organic matter accumulation in sediments (Khayat et al., 2019; Morrisey et al., 2003), we hypothesized that the sediments contained more organic matter in the late periods (especially in the last period), though that was not included in the present study. Generally, high organic matter indicates abundant food resources, facilitating the growth and reproduction of benthic macrofauna. However, excessive organic matter might lead to selectively eliminate species (e.g. infauna) due to oxygen depletion and generation of toxic by-products (e.g., ammonia and sulfide) associated with the decomposition process (Li et al., 2017; Ryu et al., 2011). Therefore, the sharp decline in the community parameters of infauna in the last sampling period might be related to the excessive organic matter in the sediments.

The composition of crabs and gastropods are considered to be more intensively influenced by the habitat changes associated with mangrove vegetation (Chen et al., 2007). Grapsid crabs (especially sesarmid species) dominated over ocypodid crabs in the mature mangrove stands, whereas Uca species and other ocypodids were more abundant than grapsids in the younger or degraded mangrove stands (Chen et al., 2007; Li et al., 2017; Macintosh et al., 2002). Our results suggested that ocypodids Ilyoplax tansuiensis, M. definitus, and Uca arcuata were more abundant in the first sampling period, and grapsids $S$. dehaani and S. plicata were absent in the initial phase but emerged later (Table 1). Most ocypodid crabs are surface deposit feeders and sesarmid crabs are capable of consuming mangrove leaf litter (Chen and Ye, 2008; Koo et al., 2019; Ravichandran et al., 2006). Thus, this may explain why the proportions of PH increased in the last sampling period (Fig. 4).

Mangrove vegetation could provide moist environments for gastropods and protect them from being washed away (Li et al., 2017). Nevertheless, a low light environment would inhibit the growth of microalgae that gastropods favor (Feng et al., 2018). A field experiment demonstrated that the abundance of gastropods dropped by $83 \%$ after removing most of the mangrove pneumatophores and the attached epiphytic algae (Skilleter and Warren, 2000). Therefore, the three gastropods, i.e., Assiminea brevicula, $C$. cingulate, and Littoraia melanostoma, contributing to the community dissimilarities among the sampling periods may be ascribe to the shifts in food resources (Table 1). Conversely, the results from Macintosh et al. (2002) and Li et al. (2017) described that gastropods (i.e., ellobiids and neritids) were more abundant in the mature stands compared to the younger stands. The abundance of arboreal gastropods such as $C$. cingulata and $L$. melanostoma may be underestimated because these fauna are usually found attached to the trunk, branches or leaves of mangrove plants (Puryono and Suryanti, 2019), due to the sampling methods used in the present study.

Although infauna and certain FFGs showed the seasonal characteristics, which might be attributed to the influence of recruitment, the seasonality in macrobenthic community structure in the present study was inconspicuous (Fig. 5; Fig. S1). For tropical and subtropical communities, more stable climate might 
minimize the seasonal variations. However, the seasonality is not the focus of this study and would not be discussed further.

Evolving to the mature state for mangroves may take about ten to twenty years, depending on the species considered (Chen et al., 2007; Pagliosa et al., 2016). From our observations the recovery of macrobenthic communities seems difficult and with many challenges, though a lush mangrove stand has been achieved. However, the restoration of macrobenthic communities is a complex and time-consuming process and also depends on the planting strategies and local environments (Ellison, 2000; Lewis, 2005). Therefore, it would be intriguing to continue exploring the development of macrobenthic community in the next decade.

\section{Conclusion}

Knowledge on the dynamics of macrobenthic communities in the mangrove afforestation process is conducive to a better understanding of the mangrove restoration at the ecosystem level. Our results showed that the structure of macrobenthic community differed significantly with the stand age of mangrove vegetation. Over time, finer sediments and lower species number, abundance, biomass, and diversity $(H)$ of benthic macrofauna were observed. In addition, the variations in the adaptabilities of epifauna and infauna and the compositions of FFGs may be related to the modification of vegetation characteristics, such as the canopy cover and root density, in afforestation process, though these were not included in the present study. These findings would provide a scientific reference for the scheme of mangrove restoration and further reach ecosystem restoration goals.

\section{Declarations}

\section{Acknowledgments}

We sincerely appreciate the support of the Third Institute of Oceanography, Ministry of Natural Resources, in the analysis of sediment environmental data. We would like to thank Lulu Yan, Wenjun Li, Guoqiang Li, Jiali Zeng, Wenjuan Tan, Deyuan Yang and Binwen Chen for their support in sample collection. All the members involved in this project are to be acknowledged here.

Funding This work was funded by the National Key Research and Development Program of China [2017YFC0506101].

Conflicts of interest/Competing interests The authors declared that they have no conflicts of interest to this work.

Ethics approval Not applicable.

Consent to participate Not applicable.

Consent for publication The authors consent to this manuscript's publication. 
Availability of data and material Not applicable.

Code availability Not applicable.

Authors' contributions Lizhe Cai conceived of the study and obtained funding. Lizhe Cai, Xiping Zhou, Sujing Fu, Xinwei Chen, Yiyong Rao, Wenqing Chen, and Bin Zheng were responsible for field and laboratory work. Lizhe Cai conducted the identification of benthic macrofauna and created many of the manuscript elements. Yiyong Rao led the data analysis and writing effort, with significant contributions to these by all authors.

\section{References}

1. Jari O, Guillaume B, Roeland MF., Dan PL, Peter M, O'Hara RM, Gavin RB, Peter LS, Henry S, Eduard HS, Helene S W., 2018. vegan: Community Ecology Package. R package version 2.5-3. https://CRAN.R-project.org/package=vegan

2. Alongi DM (2002) Present state and future of the world's mangrove forests. Environ Conserv 29:331349

3. Alongi DM (2008) Mangrove forests: resilience, protection from tsunamis, and responses to global climate change. Estuar Coast Shelf Sci 76:1-13

4. Bird ECF (1971) Mangroves as land-builders. Victorian naturalist 88:189-197

5. Bosire JO, Dahdouhguebas F, Walton M, Crona B, Lewis RR, Field CD, Kairo JG, Koedam N (2008) Functionality of restored mangroves: A review. Aquat Bot 89:251-259

6. Cannicci S, Burrows D, Fratini S, Smith TJ, Offenberg J, Dahdouhguebas F (2008) Faunal impact on vegetation structure and ecosystem function in mangrove forests: A review. Aquat Bot 89:186-200

7. Chen G, Ye Y (2008) Leaf consumption by Sesarma plicata in a mangrove forest at Jiulongjiang Estuary, China. Mar Biol 154:997-1007

8. Chen G, Ye Y, Lu C (2007) Changes of macro-benthic faunal community with stand age of rehabilitated Kandelia cande/ mangrove in Jiulongjiang Estuary, China. Ecol Eng 31:215-224

9. Chen Q, Zhao Q, Chen P, Lu H, Jian S (2018a) Eco-exergy based self-organization of the macrobenthic faunal assemblage during mangrove succession in Zhanjiang, China. Ecol Ind 95:887-894

10. Chen Q, Zhao Q, Jian S, Chen P (2018b) Changes in the functional feeding groups of macrobenthic fauna during mangrove forest succession in Zhanjiang, China. Ecol Res 33:959-970

11. Chen X, Cai L, Zhou X, Rao Y (2017) Geographical variation in oligochaete density and biomass in subtropical mangrove wetlands of China. Journal of Ocean University of China 16:925-931

12. Duke NC, Meynecke JO, Dittmann S, Ellison AM, Anger K, Berger U, Cannicci S, Diele K, Ewel KC, Field CD (2007) A world without mangroves? Science 317:41-42

13. Ellison AM (2000) Mangrove Restoration: Do We Know Enough? Restor Ecol 8:219-229 
14. Evin LA, Talley TS (2002) Influences of vegetation and abiotic environmental factors on salt marsh invertebrates. Concepts and controversies in tidal marsh ecology. Springer, Dordrecht, pp 661-707

15. Ewel KC, Twilley RR, Ong JE (1998) Different kinds of mangrove forests provide different goods and services. Global Ecology Biogeography Letters 7:83-94

16. Feng J, Guo J, Huang Q, Jiang J, Huang G, Yang Z, Lin G (2014) Changes in the community structure and diet of benthic macrofauna in invasive Spartina alterniflora wetlands following restoration with native mangroves. Wetlands 34:673-683

17. Feng J, Huang Q, Chen H, Guo J, Lin G (2018) Restoration of native mangrove wetlands can reverse diet shifts of benthic macrofauna caused by invasive cordgrass. Journal of applied ecology 55:905916

18. Field C (1999) Rehabilitation of mangrove ecosystems: an overview. Mar Pollut Bull 37:383-392

19. Giarrizzo T, Schwamborn R, Saintpaul U (2011) Utilization of carbon sources in a northern Brazilian mangrove ecosystem. Estuarine Coastal Shelf Science 95:447-457

20. Jumars PA, Dorgan KM, Lindsay SM (2015) Diet of worms emended: an update of polychaete feeding guilds. Annual review of marine science 7:497-520

21. Khayat JAA, Abdulla MA, Alatalo JM (2019) Diversity of benthic macrofauna and physical parameters of sediments in natural mangroves and in afforested mangroves three decades after compensatory planting. Aquat Sci 81:1-11

22. Kon $K$, Kurokura $H$, Tongnunui $P$ (2010) Effects of the physical structure of mangrove vegetation on a benthic faunal community. J Exp Mar Biol Ecol 383:171-180

23. Koo BJ, Kim S, Hyun J (2019) Feeding behavior of the ocypodid crab Macrophthalmus japonicus and its effects on oxygen-penetration depth and organic-matter removal in intertidal sediments. Estuarine Coastal Shelf Science 228:106366

24. Kristensen E, Bouillon S, Dittmar T, Marchand C (2008) Organic carbon dynamics in mangrove ecosystems: a review. Aquat Bot 89:201-219

25. Lana PDC, Guiss C (1991) Influence of Spartina alterniflora on structure and temporal variability of macrobenthic associations in a tidal flat of Paranagua Bay (southeastern Brazil). Mar Ecol Prog Ser 73:231-244

26. Lee SY (2008) Mangrove macrobenthos: assemblages, services and linkages. J Sea Res 59:16-29

27. Leung JY, Cheung NK (2017) Can mangrove plantation enhance the functional diversity of macrobenthic community in polluted mangroves? Mar Pollut Bull 116:454-461

28. Leung JYS (2015) Habitat heterogeneity determining the macrobenthic infaunal community in a mangrove swamp in South China: implication for plantation and plant invasion. J Coastal Res 313:624-633

29. Lewis RR (1984) Creation and restoration of coastal plant communities. CRC Press

30. Lewis RR (2005) Ecological engineering for successful management and restoration of mangrove forests. Ecol Eng 24:403-418 
31. Li YF, Du FY, Gu YG, Ning JJ, Wang LG (2017) Changes of the macrobenthic faunal community with stand age of a non-native mangrove species in Futian Mangrove National Nature Reserve, Guangdong, China. Zoological Studies 56:1-14

32. Macdonald TA, Burd B, Macdonald V, Van Roodselaar A (2010) Taxonomic and feeding guild classification for the marine benthic macroinvertebrates of the Strait of Georgia, British Columbia. Fisheries and Oceans Canada, Pêches et océans Canada

33. Macintosh D, Ashton E, Havanon S (2002) Mangrove rehabilitation and intertidal biodiversity: a study in the Ranong mangrove ecosystem, Thailand. Estuarine, Coastal and Shelf Science 55, 331-345

34. Morrisey D, Skilleter G, Ellis J, Burns B, Kemp C, Burt K (2003) Differences in benthic fauna and sediment among mangrove (Avicennia marina var. australasica) stands of different ages in New Zealand. Estuarine, Coastal and Shelf Science 56, 581-592

35. Nagelkerken I, Blaber SJM, Bouillon S, Green P, Haywood M, Kirton LG, Meynecke J, Pawlik JR, Penrose HM, Sasekumar A (2008) The habitat function of mangroves for terrestrial and marine fauna: A review. Aquat Bot 89:155-185

36. Pagliosa PR, Oortman MS, Rovai AS, Soriano-Sierra EJ (2016) Is mangrove planting insufficient for benthic macrofaunal recovery when environmental stress is persistent? Ecol Eng 95:290-301

37. Peterson CH, Summerson HC, Duncan PB (1984) The influence of seagrass cover on population structure and individual growth rate of a suspension-feeding bivalve, Mercenaria mercenaria. $\mathrm{J}$ Mar Res 42:123-138

38. Puryono S, Suryanti S (2019) Gastropod Diversity in Mangrove Forests of Mojo Village, Ulujami District, Pemalang Regency, Indonesia. Journal of Ecological Engineering 20:165-173

39. Ravichandran S, Kannupandi T, Kathiresan K (2006) Mangrove leaf litter processing by Sesarmid crabs. Cey J Sci (Bio Sci) 35:107-114

40. Ryu J, Khim JS, Kang S, Kang D, Lee C, Koh C (2011) The impact of heavy metal pollution gradients in sediments on benthic macrofauna at population and community levels. Environ Pollut 159:26222629

41. Skilleter GA, Warren S (2000) Effects of habitat modification in mangroves on the structure of mollusc and crab assemblages. J Exp Mar Biol Ecol 244:107-129

42. Tang J, Ye S, Chen X, Yang H, Sun X, Wang F, Wen Q, Chen S (2018) Coastal blue carbon: Concept, study method, and the application to ecological restoration. Science China-earth Sciences 61:637646

43. Walters BB, Ronnback P, Kovacs JM, Crona B, Hussain SA, Badola R, Primavera JH, Barbier EB, Dahdouhguebas $F$ (2008) Ethnobiology, socio-economics and management of mangrove forests: $A$ review. Aquat Bot 89:220-236

44. Whitcraft CR, Levin LA (2007) Regulation of benthic algal and animal communities by salt marsh plants: impact of shading. Ecology 88:904-917

\section{Figures}




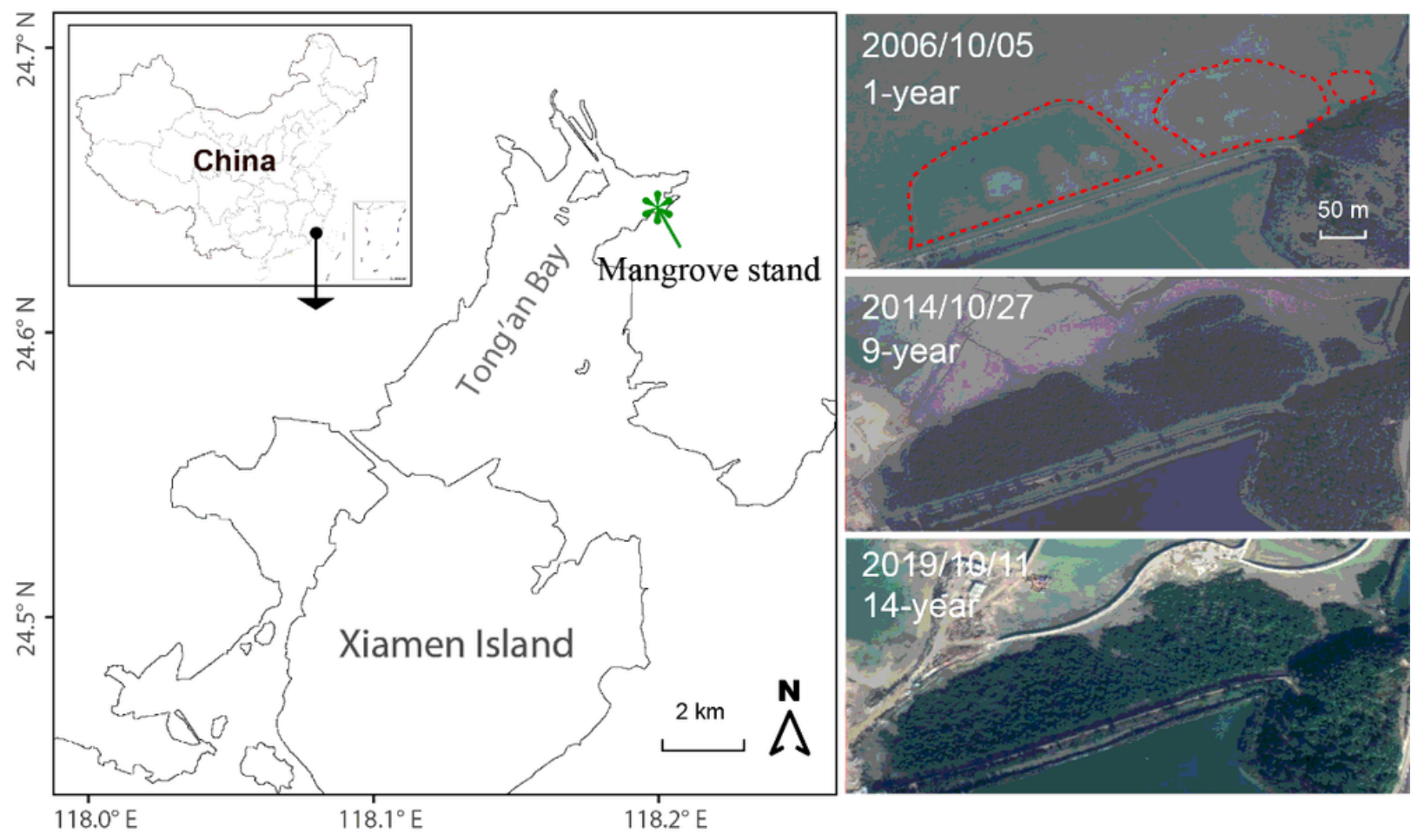

\section{Figure 1}

Location and satellite images of the mangrove stand in Xiamen Tong'an Bay, China. The satellite images on the right were taken in 2006, 2014, and 2019, showing the canopy of mangroves (red dashed areas) of 1-year, 9-year, and 14-year. 


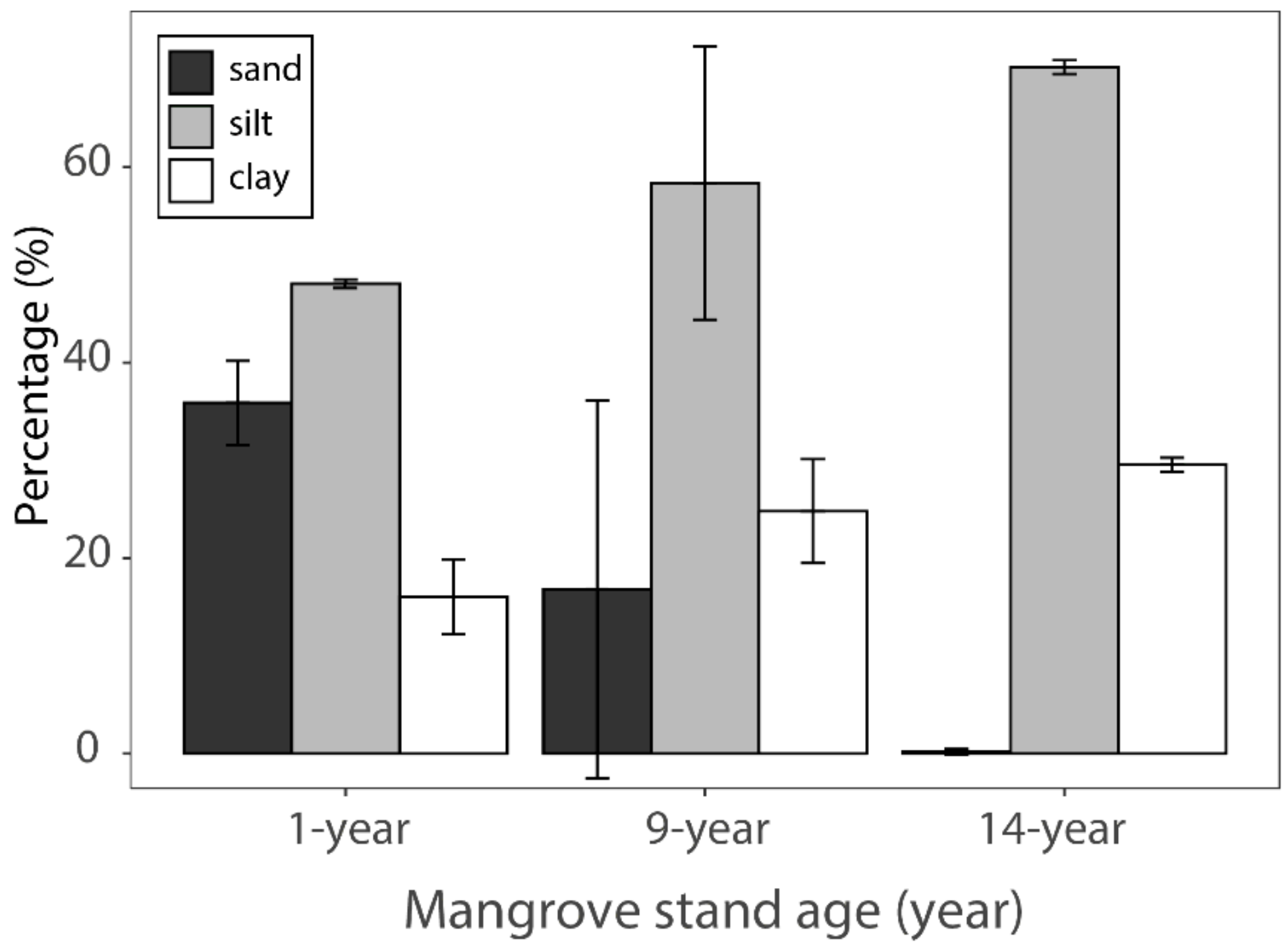

Figure 2

Temporal variations in the percentages (mean \pm SD) of the sediment grain size fractions in the mangrove stand in Xiamen Tong'an Bay 

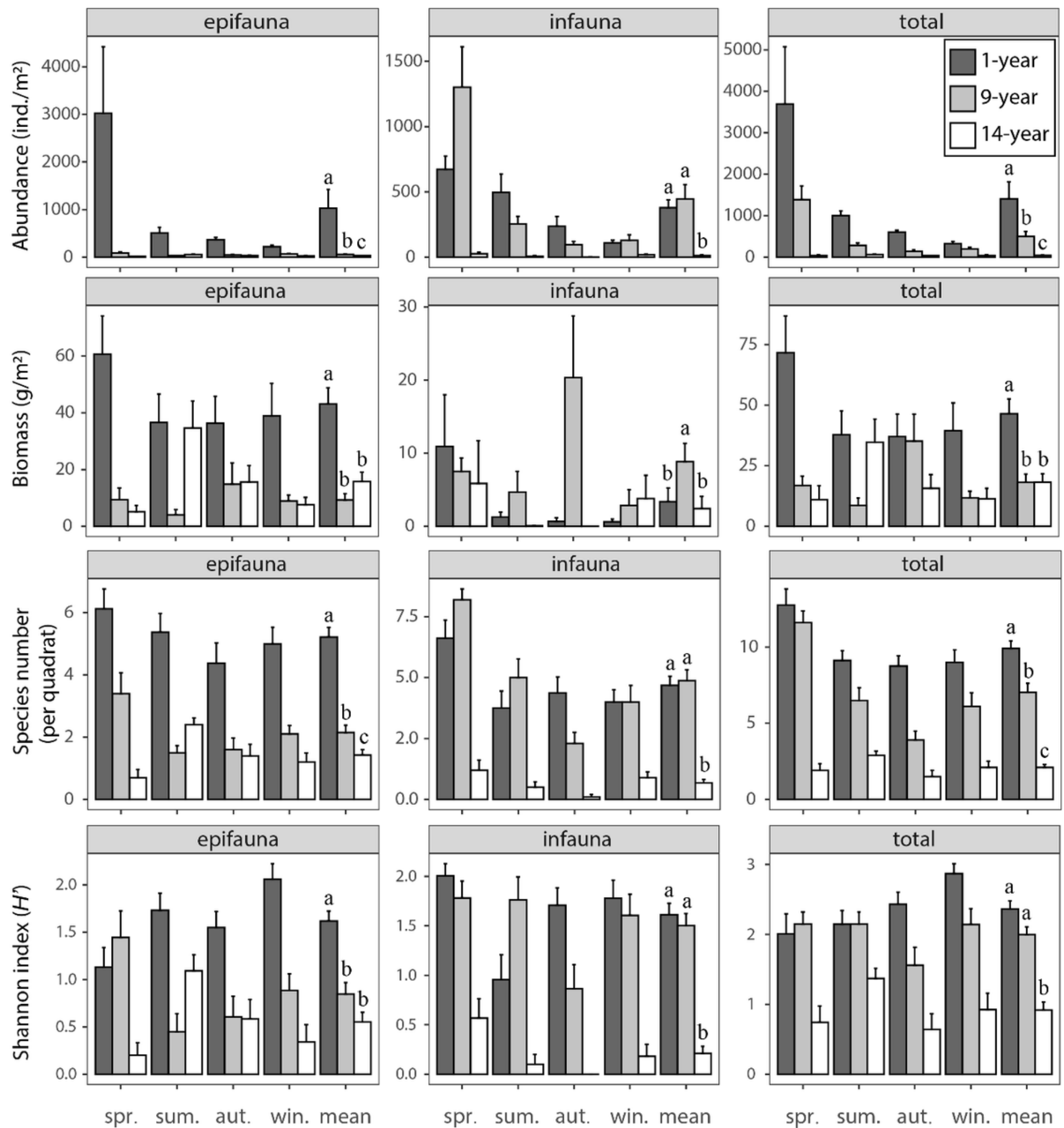

Figure 3

Temporal variations in the species number, abundance, biomass, and Shannon index ( $\left.\mathrm{H}^{\prime}\right)$ of macrobenthic community in the mangrove stand in Xiamen Tong'an Bay. Error bars represent the standard errors. Different lowercase letters indicate significant differences between stand age groups Spr., sum., aut., and win. represent spring, summer, autumn, and winter, respectively. 

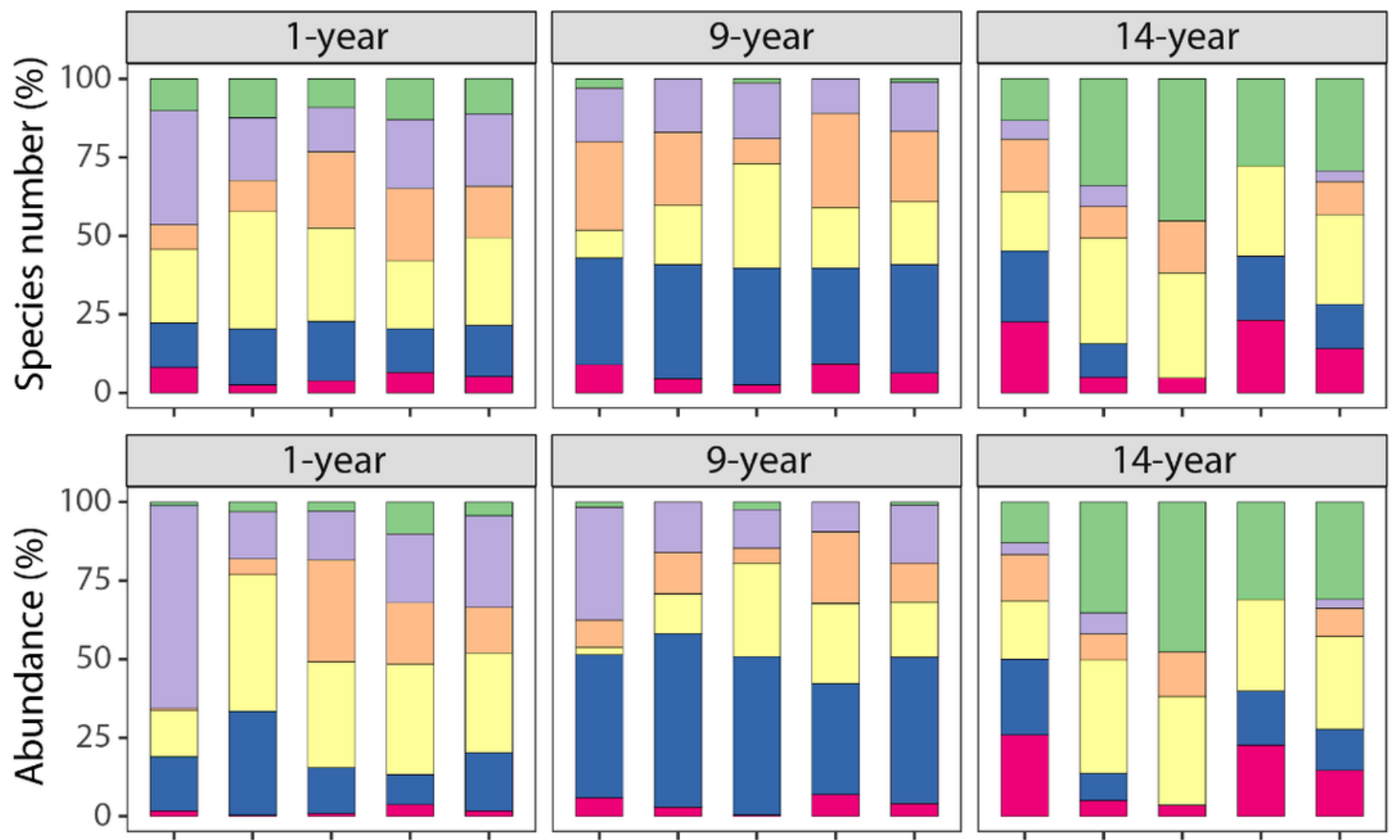

FFGs
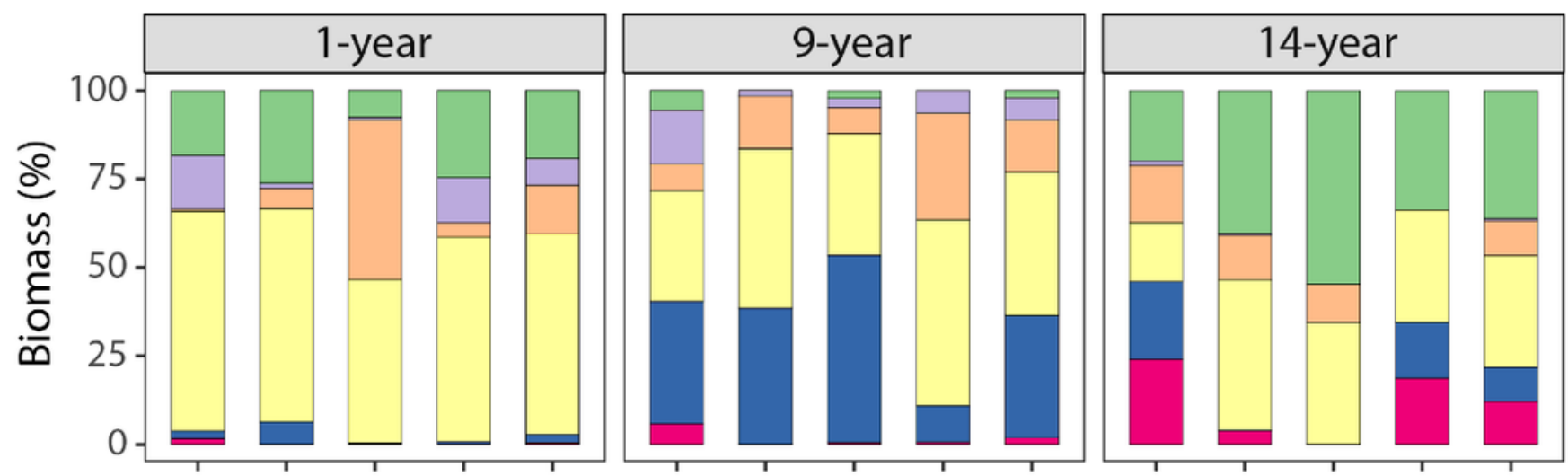

spr. sum. aut. win. mean

spr. sum. aut. win. mean

spr. sum. aut. win. mean

\section{Figure 4}

Temporal variations in the proportions of different functional feeding groups (FFGs) in the mangrove stand in Xiamen Tong'an Bay. Spr., sum., aut., and win. represent spring, summer, autumn, and winter, respectively. $\mathrm{PH}, \mathrm{PL}, \mathrm{CA}, \mathrm{SD}, \mathrm{SSD}$, and $\mathrm{OM}$ represent phytophages, planktophages, carnivores, surface deposit feeders, subsurface deposit feeder and omnivores, respectively. 


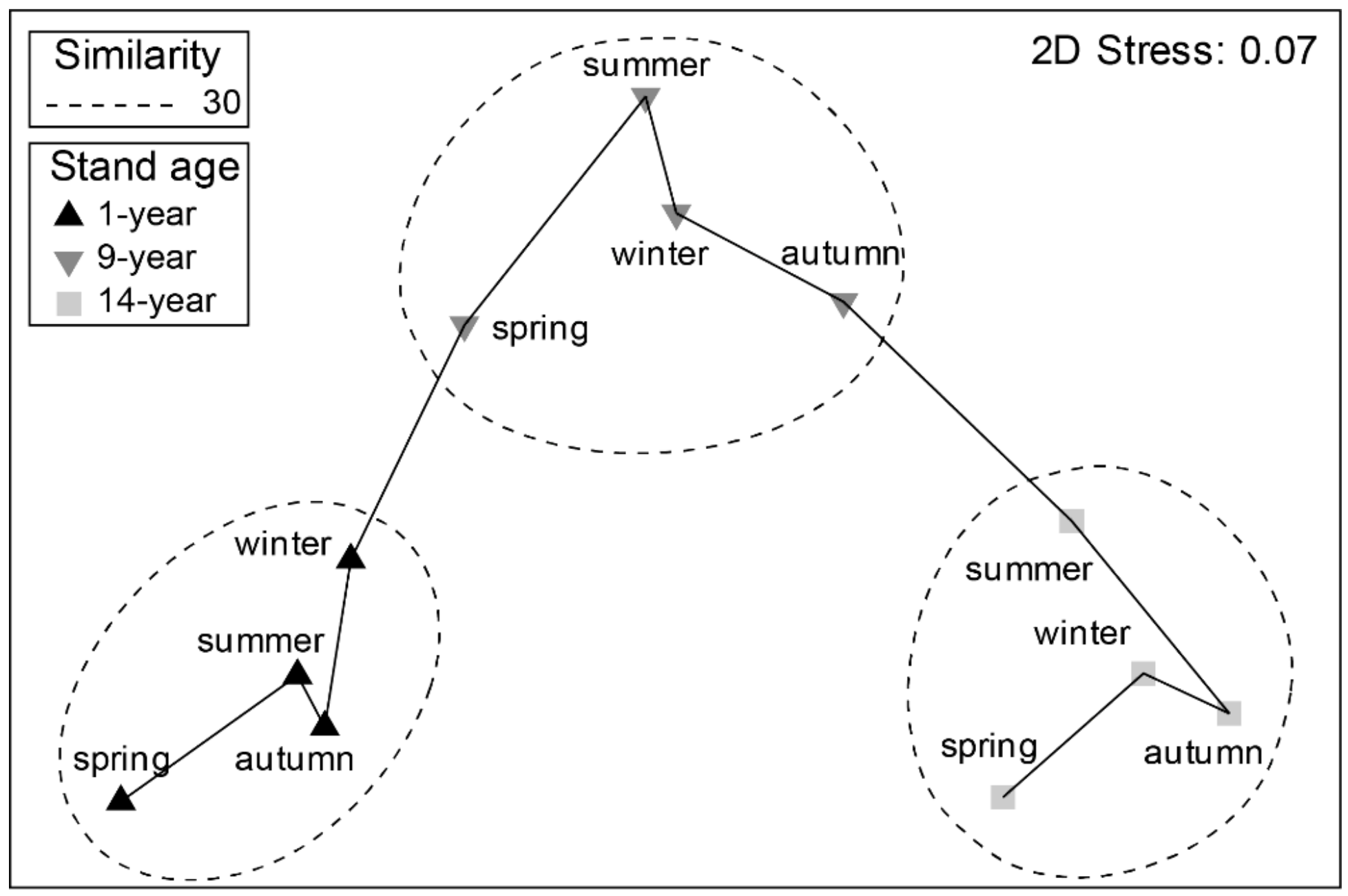

Figure 5

nMDS ordination plot of macrobenthic communities based on the Bray-Curtis similarity of square-root transformed abundance data in the mangrove stand in Xiamen Tong'an Bay. Dashed circles represent the temporal groups exhibiting significant differences (SIMPROF, $\mathrm{P}<0.05$ ) and grouping at the similarity of $30 \%$ (CLUSTER) simultaneously. The black line represents the minimum spanning tree.

\section{Supplementary Files}

This is a list of supplementary files associated with this preprint. Click to download.

- Onlinefloatimage1.png

- SupplementaryMaterial.docx 